\title{
Festival of Audiovisual Micro-Stories in Psychology (Microfest): An Innovative Teaching Project for Students of Audiovisual Communication and Journalism
}

\author{
Rebeca Bautista Ortuño*(D), Beatriz Bonete-López (D) and Raquel Lorente-Martínez (D)
}

check for updates

Citation: Bautista Ortuño, Rebeca, Beatriz Bonete-López, and Raquel Lorente-Martínez. 2021. Festival of Audiovisual Micro-Stories in Psychology (Microfest): An Innovative Teaching Project for Students of Audiovisual Communication and Journalism. Administrative Sciences 11: 120. https://doi.org/10.3390/ admsci11040120

Received: 9 August 2021

Accepted: 11 October 2021

Published: 20 October 2021

Publisher's Note: MDPI stays neutral with regard to jurisdictional claims in published maps and institutional affiliations.

Copyright: (C) 2021 by the authors. Licensee MDPI, Basel, Switzerland. This article is an open access article distributed under the terms and conditions of the Creative Commons Attribution (CC BY) license (https:// creativecommons.org/licenses/by/ $4.0 /)$.
Department of Health Psychology, Miguel Hernández University, 03202 Elche, Spain; bbonete@umh.es (B.B.-L.); rlorente@umh.es (R.L.-M.)

* Correspondence: rbautista@umh.es

\begin{abstract}
Introductory psychology courses can be demotivating for students of social sciences degrees such as Audiovisual Communication and Journalism. Although the importance of this subject is more than justified, it is essential to design and apply innovative strategies that stimulate the teaching-learning process among first-year students, so that, through activities other than traditional lectures, their interest in behavioural sciences is aroused and they understand the importance of this subject for the future development of their professional careers. The aim of this paper is to present MICROFEST, a PIEU-UMH teaching innovation project, which has been applied as part of the continuous evaluation of students of the Fundamentals of Psychology course, taught in the first year of the Audiovisual Communication, Journalism and Joint Honours degree programmes at the Miguel Hernández University, during the 2020/21 academic year $(n=167)$. Through a format similar to that of a short film festival, an activity was proposed that involves the development of a series of sequential tasks aimed at creating, in pairs, a fictional audiovisual micro-story that addresses content or a theme directly related to psychology. The results obtained after the implementation of the project during the four months of the course show that the students of the three degree programmes presented a high level of performance in this part of the course, have favourable attitudes towards it and valued the initiative very positively. The indicators of satisfaction with the project were found to be good predictors of motivation towards the subject as a whole. Thus, continuance of the design and application of teaching innovation strategies that favour the teaching-learning process is recommended, and students' satisfaction and attitudes toward it.
\end{abstract}

Keywords: psychology; micro-stories; audiovisual communication; journalism; learning innovation

\section{Introduction}

The first year of any higher education degree is characterised by the inclusion of basic subjects whose main objective is mainly to transmit theoretical knowledge. This type of training is required for students to be able to assimilate new technical and specific knowledge inherent to their field of specialisation, adapting this new information to their pre-acquired mental schemas (Piaget 1976). Moreover, it is also usual for the curricula of all degree programmes to include core subjects from other disciplines, especially in the field of social sciences. In this sense, introductory subjects from psychology in degrees belonging to fields of knowledge other than health, such as, for example, Journalism or Audiovisual Communication, could sometimes be demotivating for students starting their studies. Although the importance of this discipline for future professional development in these degrees is justified in their curricula, it is essential that teachers design and apply innovative strategies in the classroom that motivate and stimulate the teaching-learning process of the basic aspects of psychology among first-year students.

The paper aims to present the results of the University Educational Innovation Project called MICROFEST that was applied in a behavioural science subject in Journalism, Audio- 
visual Communication, and Joint Honours Audiovisual Communication and Journalism degrees. This project aimed to arouse the interest of these students in psychology, encourage their participation in the continuous assessment of the subject and promote satisfaction with the teaching provided.

Below is a description of the state of the art with regard to teaching innovation and teaching-learning strategies that has produced good results in the field of higher education and that justifies the application of the project implemented in this study. Following this, the aims of the study and the method implemented are presented. Finally, we present the results, a discussion of them and the most relevant conclusions once the MICROFEST project was implemented during the 2020/21 academic year.

\subsection{State of the Art}

Achieving an adequate level of competence is fundamental in 21st Century education, given that, in a transversal way, students learn with technology and need to use and appropriate technology to achieve the learning objectives proposed in formal education (Bujanda-Bujanda et al. 2014). Digitisation was already required within the academic curricula of students and among the competences required of university teaching staff. This not only has become much more essential in the academic and professional sphere in the current social and educational context caused by the COVID-19 pandemic, but also in all areas of individual development.

Recently, the European Union established a common framework for the digital competence of educators. This framework includes 22 competences in six areas: (1) professional commitment; (2) digital content; (3) teaching and learning; (4) assessment and feedback; (5) empowering students; and (6) developing the digital competence of students. The European Framework for the Digital Competence of Educators (DigCompEdu) explains how digital technologies can be used to improve and innovate education, facilitating their adaptation to any type of context (European Commision 2021; Redecker 2017).

In the Spanish educational system, educational innovation is included in the legislation, establishing that "educational Administrations are responsible for promoting and recognising it" (Ministerio de Educación 2011, p. 21). At the Miguel Hernández University, the Vice-Rectorate for Studies is the competent body for promoting teaching innovation and, among all its actions in this area, it organises an annual competition for university educational innovation projects within the framework of their subjects and offers a free 300-h training course in educational technologies to the university's teaching staff, which has a specific module on active methodologies with flipped classrooms and gamification.

Innovative initiatives in university contexts must, in turn, be based on theoretical models that encourage student learning, as well as the development of the high-level cognitive skills required in higher education. Bloom and other higher education specialists developed a system for classifying learning objectives based on the cognitive domains to be achieved, which were organised in a hierarchy from the simplest to the most complex (knowledge, understanding, application, analysis, synthesis and assessment). In its subsequent revised version, a two-dimensional model was proposed: (1) knowledge, which would include knowledge of facts, concepts, procedures and meta-knowledge; and (2) the cognitive processes involved in learning, organised from the lowest to the highest level: remembering, understanding, applying, analysing, assessing and creating. The components included in both dimensions were organised in a hierarchy in a more flexible way than in the original model of Bloom and his collaborators, thus facilitating the teacher's task when it comes to planning students' learning activities (Krathwohl 2002).

Both models have been used in educational innovation studies with positive results for developing real-world skills and competences in the field of financial accounting (Huber et al. 2017); for improving students' perceived quality of the description of the curriculum in a psychology subject, which, after applying the taxonomy in the description of learning objectives, is perceived as more explicit and understandable for achieving the 
desired knowledge (Malá and Čerešník 2015); and as a frame of reference for the design of training in new information technologies for university teachers (Turcsányi-Szabó 2012).

In addition to the theoretical approach to teaching-learning, other fundamental aspects of university teaching are students' satisfaction and motivation to learn. Motivation and emotions are fundamental human psychological processes in the acquisition of learning (Garrote Rojas et al. 2016). One technique for motivating university students in the learning process that is gaining more and more ground is gamification (Ávila and Betancur 2017). Following the approach of Lee and Hammer (2011), gamification is the use of game mechanics, their dynamics and their frameworks, to promote desired behaviours. The aim of gamification is to motivate participants to engage in a specific and desirable behaviour (Doherty et al. 2017). A game is an attention trigger and emerges as an alternative to complement traditional teaching based on lecture-based teaching, compensating for commitment and motivation problems. It is also useful for improving cognitive, emotional and social strategies (Ávila and Betancur 2017). However, for its application, it should be borne in mind that teachers first need to master its principles and have a high level of digital competence (Dreimane 2019).

Another aspect that has been getting more and more attention in the dynamisation of education is the introduction of peer review and/or assessment systems, which is a collaborative activity in which students consider, evaluate and generate feedback on each other's work (Indriasari et al. 2020). Among the benefits offered are the development of cognitive, social and affective skills (Topping 1998), and it has also been shown to improve analytical and communication skills (Søndergaard and Mulder 2012) and is therefore considered to be a form of assessment that reinforces the philosophy of gamification.

In light of the above, the creation of innovative teaching activities that facilitate the acquisition of knowledge that progressively involve cognitive processes from a low to a high level, in which participation is also encouraged through the game and students are involved in the assessment process, could have a positive impact on the motivation and satisfaction of university students with the teaching received. Following these premises, the authors of this study took the educational technologies training of University Miguel Hernández in the 2019/2020 academic year. Then, the MICROFEST project, which is presented in this paper, was designed and implemented in the Fundamentals of Psychology course, which is taught in the Audiovisual Communication, Journalism and Joint Honours degree programmes at the same university.

For this purpose, a series of tasks were designed and sequenced to allow students to acquire knowledge about concepts and procedures for making an audiovisual micro-story on psychology. Through the staging of a short film festival, we considered the project would be of interest to the profile of students of these degrees since it allowed one to relate the communication and psychology disciplines. In addition to the knowledge dimension, the project also includes all cognitive dimensions involved in learning, according to Bloom's revised taxonomy: (1) recalling information learnt in theoretical classes and of their knowledge of the world; (2) understanding the activity instructions and theoretical contents; (3) applying information search procedures for the development of the script of the audiovisual micro-story and the editing and presentation of the audiovisual material; (4) analysing a particular psychological theme and relating it to specific examples from real life; (5) assessing and revising the micro-story script according to the standards indicated by the teachers; and (6) creating an audiovisual micro-story that correctly reflects the chosen and previously substantiated theme.

The general objective of this paper is to describe the characteristics of the innovative teaching project designed, as well as the empirical study carried out to assess the results achieved after the implementation of the initiative during the 2020/21 academic year.

\subsection{Objectives of the Study}

1. To describe the academic performance, satisfaction, achievements and attitudes towards the Fundamentals of Psychology course for students of Audiovisual Commu- 
nication, Journalism and Joint Honours at the Miguel Hernández University, during the 2020/2021 academic year, after completing this PIEU-UMH university education innovation project called MICROFEST.

2. To determine whether there are any differences in the performance, satisfaction and attitudes towards the subject depending on the degree, given that the project was implemented under different conditions: compulsory and with greater weight in the subject (in Audiovisual Communication and Journalism), or voluntary and with less weight on the final grade (in Joint Honours).

3. To analyse the relationship between the attitudes and satisfaction achieved by students after taking part in the project and to determine the weight of satisfaction and the achievements attained after taking part in order to explain and predict assessment indicators for the subject.

\section{Method}

\subsection{Design}

Empirical quantitative research was conducted using a descriptive and ex post facto simple retrospective design with one group study.

\subsection{Participants}

This project was aimed at the population of 201 students enrolled in the 2020/2021 academic year in the Fundamentals of Psychology course in the Audiovisual Communication (CAU), Journalism (P) and Joint Honours (CAUP) degree programmes at the Miguel Hernández University. The final sample was made up of 167 students $(29.9 \%$ CAU, $46.7 \%$ P and $23.4 \%$ CAUP), aged between 18 and $41(\bar{X}=19.4 ; S D=2.7)$. Finally, $44.9 \%$ of the sample identify as men, $53.3 \%$ as women, $1.2 \%$ identify as another gender and one participant $(0.6 \%)$ prefers not to answer.

The criteria established for assessing participation in the project were: (a) delivery of the following tasks, in the established format and on the established date: (1) organisation in pairs and group assignment through the virtual campus, (2) development and delivery of the script justification and development form, (3) delivery of the micro-story developed through its YouTube link and by means of the shared folder in Google Drive, (4) completion of the assessments of the audiovisual micro-stories developed by the other classmates and (5) completion of the questionnaire at the end of the project; and (b) attendance record at the following sessions: (1) presentation of PIEU-UMH and MICROFEST I, (2) seminar on communication skills, (3) screening and assessment of micro-stories, and (4) MICROFEST I Micro-Stories Festival.

\subsection{Microfest Project Implemented: General Characteristics}

MICROFEST is an innovative teaching project of the Miguel Hernández University (PIEU-UMH) which has been applied as part of the continuous assessment of students of the Fundamentals of Psychology course, taught in the first year of the Audiovisual Communication, Journalism and Joint Honours degree programmes at the Miguel Hernández University, during the 2020/21 academic year.

Based on a format similar to that of a short film festival, the idea is to organise an activity that involves the development of a series of assessable sequential tasks aimed at the creation, in pairs, of a fictional audiovisual micro-story that addresses a content or theme directly related to psychology. Through this activity, it is hoped that the motivation, participation and quality of the work presented in the Fundamentals of Psychology course will improve among students. Furthermore, the PIEU-UMH has been designed to develop eight specific competences from four different areas of DigCompEdu (Table 1). 
Table 1. DigCompEdu digital competences developed with the MICROFEST project (Source: European Commision 2021).

\begin{tabular}{|c|c|}
\hline Area & Pedagogical Competences Developed by the Teachers \\
\hline $\begin{array}{l}\text { 3. Teaching and } \\
\text { Learning }\end{array}$ & $\begin{array}{l}\text { 3.1. Teaching: to programme and implement digital devices and } \\
\text { resources in the teaching process to improve the effectiveness of } \\
\text { teaching interventions. To manage and coordinate digital teaching } \\
\text { interventions appropriately. To experiment with and develop new } \\
\text { pedagogical formats and methods for teaching. } \\
\text { 3.2. Guidance and learning support: to use digital technologies and } \\
\text { services to improve individual and group interaction with students } \\
\text { inside and outside the teaching sessions. To use digital technologies } \\
\text { to offer relevant and specific guidance and assistance. } \\
\text { To experiment with and develop new ways and formats for offering } \\
\text { guidance and support. } \\
\text { 3.3. Collaborative learning: to use digital technologies to encourage } \\
\text { and improve collaboration between students. To enable students to } \\
\text { use digital technologies as part of the collaborative tasks as a means } \\
\text { for improving communication, cooperation and joint knowledge } \\
\text { creation. }\end{array}$ \\
\hline $\begin{array}{l}\text { 4. Assessment and } \\
\text { Feedback }\end{array}$ & $\begin{array}{l}\text { 4.1. Assessment strategies: To use digital technologies for formative } \\
\text { and summative assessment. To improve the diversity and suitability } \\
\text { of assessment formats and approaches. }\end{array}$ \\
\hline $\begin{array}{l}\text { 5. Student } \\
\text { empowerment }\end{array}$ & $\begin{array}{l}\text { 5.3. Active engagement of students in their own learning: to use } \\
\text { digital technologies to improve students' active engagement with a } \\
\text { subject. To integrate digital technologies in pedagogical strategies } \\
\text { that enhance students' transversal competences, complex thinking } \\
\text { and creative expression. To open up learning to new domains from } \\
\text { the real world that involve the students themselves in practical } \\
\text { activities, scientific research or in solving complex problems or which, } \\
\text { by any other means, encourage the active participation of students in } \\
\text { complex themes. }\end{array}$ \\
\hline Area & Competences Developed In Students \\
\hline $\begin{array}{l}\text { 6. Development of } \\
\text { students' digital } \\
\text { competence }\end{array}$ & $\begin{array}{l}\text { 6.1 Information and media literacy: to incorporate learning activities, } \\
\text { tasks and assessments that require students to express their } \\
\text { information needs; to locate information and resources in digital } \\
\text { environments; and to organise, process, analyse and interpret the } \\
\text { information and to compare and assess the credibility and reliability } \\
\text { of the information and its sources in a critical manner. } \\
\text { 6.2. Digital communication and collaboration: to incorporate learning } \\
\text { activities, tasks and assessments that require students to use digital } \\
\text { technologies in an effective and responsible way for communication, } \\
\text { collaboration and civic engagement. } \\
\text { 6.3. Digital content creation: to include learning activities, tasks and } \\
\text { assessments that require students to express themselves through } \\
\text { digital means, as well as to modify and create digital content in } \\
\text { different formats. To teach students how copyright and licences affect } \\
\text { digital content, how to reference sources and how to attribute } \\
\text { licences. }\end{array}$ \\
\hline
\end{tabular}

Note: The authors made this extraction taking into account all the activities of students and teachers that required the use of digital tools during the implementation of the project.

\subsubsection{Project Objectives}

The MICROFEST project pursues the following objectives:

1. To encourage positive attitudes and interest in psychology among Audiovisual Communication, Journalism and Joint Honours degree students.

2. To reinforce the development of skills that enable students: (a) to search for information and document it correctly in psychology-related topics to establish the content of their work; (b) to synthesise theoretical knowledge in order to express it in a very 
short audiovisual creation; (c) to put theoretical knowledge of recording and editing videos into practice and adapt to the means available to each student; (d) to train and put communication and oral expression skills into practice; (e) to acquire responsibility for assessing the work of their peers fairly; and, ultimately, (f) to create works that follow all the established quality criteria and standards for format and content, which allow them to compete with their peers in order to qualify for and take part in MICROFEST I.

\subsubsection{Timeline of Activities}

After holding several prior meetings in December 2020, in which the teachers involved in the development and implementation of the project took part, the activities and tasks were planned, and the materials required to implement and disseminate them were prepared. During February 2021, at the start of each degree course, the project was presented to the students, explaining all the activities and tasks to be carried out over the following four months, as shown in Figure 1.

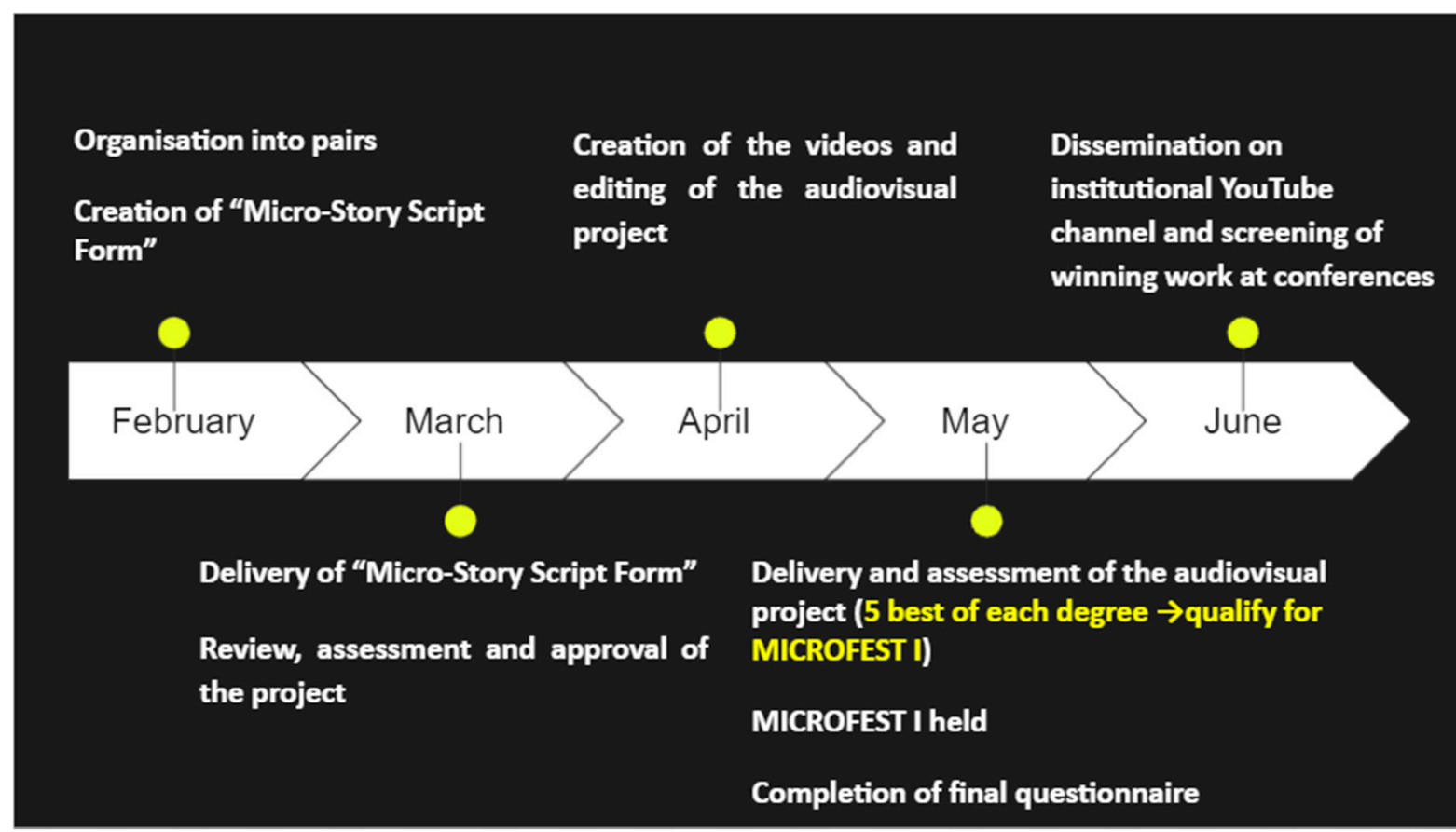

Figure 1. MICROFEST project timeline.

\subsection{Variables and Measurement Instruments}

(a) Performance

The performance of the participating students was assessed by means of a direct achievement indicator such as the grades obtained in the project by the participating students. To obtain the grades, two indicators were taken into account: (1) teachers' assessment of the form for the development of the Audiovisual Micro-Story Script (scale $0-10 ; 33.3 \%$ of the total grade for the project); and (2) arithmetic means for the assessment by the teachers and participating students of the work created by the students, through the following items (scale $0-10 ; 66.7 \%$ of the total grade for the project): the degree to which the creation correctly represents the chosen theme, assessment of creativity/originality, general assessment of the creation and the degree to which the author(s) have correctly shown verbal, non-verbal and paraverbal communication skills in the presentation part of the work (Appendix A). 
The direct grades on the quantitative 0 to 10 scale were also transformed into a qualitative scale, as follows: 0 to $4.99=$ Fail; 5 to $6.99=$ Pass; 7 to $8.99=$ Excellent and 9 to $10=$ Outstanding.

(b) Satisfaction and achievements attained with the project

To assess this variable, an ad hoc instrument made up of five items (Appendix B), with a ten-point response scale (1-10), was created. The aspects assessed were: to what extent has the project served to (1) increase his/her interest in psychology, (2) apply theoretical knowledge in a practical way (3) to raise satisfaction with the subject; (4) to what extent would they recommend future students to take part in this initiative; and (5) degree of overall satisfaction with the project. The scale is reliable and its Cronbach's Alpha $=0.90$.

(c) Attitudes towards the subject of The Fundamentals of Psychology

To assess this variable, an ad hoc questionnaire, originally made up of six items in the form of statements related to the assessment of the subject of The Fundamentals of Psychology, with a ten-point response scale (1-10) to assess the degree of agreement with each of them, was constructed. Half of the items were written in reverse to prevent the phenomenon of acquiescence. To ensure content validity, they were developed in pairs, addressing each aspect or dimension of the attitude: beliefs, emotions and behavioural intention. After analysing their reliability, it was decided to eliminate two of the items that reduced the consistency of the instrument. The final scale is made up of four items (Appendix C) and is highly reliable (Cronbach Alpha $=0.90$ ).

\subsection{Procedure}

Once the procedure had been included as part of the continuous assessment of the subject and incorporated into the teaching guides for each degree course, it was presented to the students in February 2021, on the start date of each course. That day, when we were presenting the contents, we warned them that we were going to carry out an educational innovation to make the subject more practical this year by developing digital competences related to their future career. By doing so, even though the contents were not directly related to their studies (e.g., psychology, history and areas of applied psychology), we hoped that the dynamics of the subject would awaken their interest in psychology.

In two of the degree courses, Audiovisual Communication and Journalism, the project was proposed as a compulsory activity, accounting for 30\% of the total grade for the subject, while in the Joint Honours Audiovisual Communication and Journalism degree programme, it was incorporated as a voluntary activity, with a weight of $10 \%$ of the final grade.

Listed below are the activities proposed that the participating students and teachers involved have been carrying out, in accordance with the timeline set out above (Figure 1):

1. Organisation of students into pairs and self-assignment of the group through an application on the Virtual Campus for the subject.

2. Selection of a psychological phenomenon or concept and completion of the form for the development of the script of the audiovisual micro-story (Appendix D). This task involves each pair researching the scientific literature on the theme selected, locating the concept within the syllabus for the subject, justifying their choice, and making a first outline of the script that they will follow to represent the psychological theme selected for their creation. Delivery will be by means of a task created in the Virtual Campus.

3. Review and assessment of the form by the teachers and approval of those projects deemed to be suitable. Guidance and setting of a new deadline for those requiring improvement.

4. Creation and editing of the audiovisual work, which contains two parts: (1) presentation by the author(s) of the work and the theme chosen, displaying the verbal, non-verbal and paraverbal communication skills presented in a seminar on communication skills, which is organised as part of the course (with a maximum duration 
of $1 \mathrm{~min}$ ); and (2) the creation or the micro-story itself (with a maximum duration of $2 \mathrm{~min}$ ).

5. Delivery of the work in two formats: through a YouTube link and sharing it with the teachers via Google Drive in order to download and store it on an external hard drive.

6. Dual-mode screening and assessment session (development of the face-to-face and online sessions simultaneously). After the screening of each work, students and teachers have access to a Google Forms form available on the Virtual Campus for the subject (Appendix A), with which they will assess the following aspects of each work: the extent to which the creation represents the chosen theme correctly; an assessment of the creativity/originality; general assessment of the creation; and the degree to which the author(s) have correctly displayed verbal, non-verbal and paraverbal communication skills in the presentation part of the work. From the sum of the weighted parts corresponding to the assessment of the form by the teachers, and the arithmetic means of all the assessments of each creation carried out by teachers and students, the participants' grades for this part of the subject are extracted. The five works with the best average grades in the general assessment item for each course qualify to take part in MICROFEST I.

7. Holding MICROFEST I in dual mode, with the attendance of students and teachers from the three degree programmes involved. Screening of the 15 micro-stories that qualified ( 5 from each degree) and online voting by the students using the same general assessment item used in the assessment of the works. In order to control the possible influence on the votes of students from the degree programme to which the author(s) of the participating micro-stories belong, also bearing in mind that the groups are not balanced, each student from a particular degree may only assess works submitted by students from degree programmes other than the one they are studying. The work with the best average grade is declared the winner.

8. Creation of an institutional YouTube channel for MICROFEST I to disseminate the 15 micro-stories that qualified and, among them, the winner.

9. Online completion by students of the anonymous questionnaire consisting of the scale of satisfaction with the project (Appendix B) and attitudes towards the subject (Appendix C), submitted in Google Forms format, through the Virtual Campus.

10. Dissemination of the initiative, the results of the project and the winning micro-story in scientific forums on educational innovation.

After the completion of the project, the winning micro-story was the one called "Memoria de pez (Memory of a fish)", made by two students from the Audiovisual Communication degree programme, which can be accessed via the following link: https: / / www.youtube.com/watch?v=7Z5umSwI5S4 (accessed on 26 July 2021).

The 15 creations that took part in MICROFEST I can be viewed in the following playlist, created within Miguel Hernández University's institutional YouTube channel: https:/ / www.youtube.com/playlist?list=PLCIKgnzRFYe7m_bpdijLIO-v3fbfOS4Pu (accessed on 26 July 2021).

\subsection{Data Analysis}

A descriptive analysis was carried out to determine the characteristics of the sample of participants, as well as the rest of the study variables. ANOVA 1F was applied to analyse the differences in the performance achieved, satisfaction with the project and attitudes towards the subject, depending on the degree programme of the sample of participating students, calculating the size of the effect in those contrasts that were statistically significant. Pearson's coefficient correlation was obtained between the total scores on the attitude and satisfaction scales in order to analyse the relationship between the two variables. Finally, a multiple linear regression analysis was carried out to determine the weight of each indicator of satisfaction with the initiative in the attitudes towards the subject presented by the students. To carry out the analysis, the IBM SPSS Statistics 26 statistical package was used. 


\section{Results}

\subsection{Descriptive Analysis}

(a) Performance

After carrying out the assessment of the sequential activities involved in the project, the mean of the grades obtained by the students was $8.35(\mathrm{SD}=0.6)$, the minimum score achieved was 5.61 and the maximum was 9.49. With regard to the distribution of the grades, the vast majority obtained a grade of Excellent (86.4\%), followed by $12.4 \%$ of participants that achieved a grade of Outstanding (Figure 2). These student performance results, coupled with the fact that there is an absence of failure, indicate that the project has been successful.

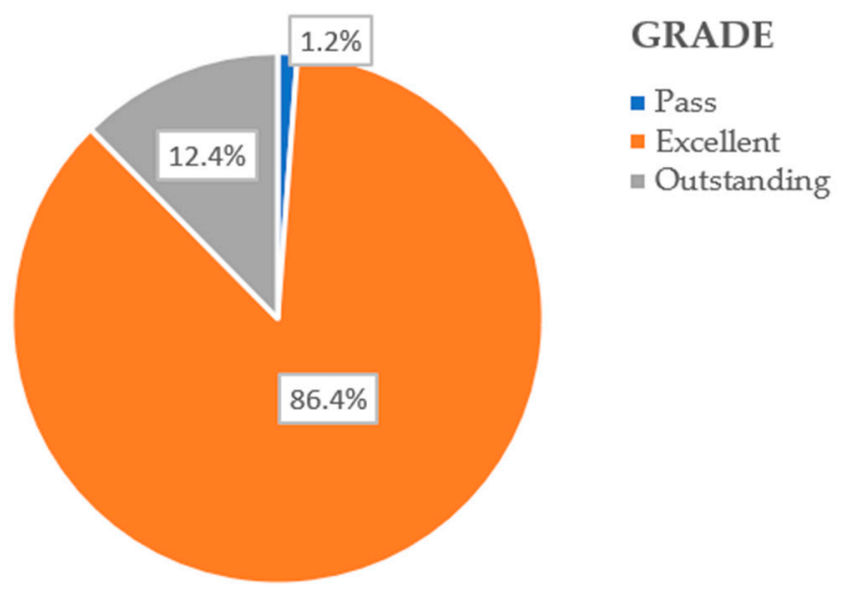

Figure 2. Distribution of grades in the project.

Finally, the differences observed at the sample level (Table 2) in the average grades of Audiovisual Communication and Journalism students, compared to those achieved in the Joint Honours degree, are statistically significant $(F=46.635 ; p=0.000)$, with a mean effect size $\left(\eta^{2}=0.36\right)$, whereby it can be affirmed that the quality of the works submitted, on which the assessments made are based, was lower in the degree course, in which the activity was voluntary and had a lower weight in the total grade for the subject.

Table 2. Descriptions of the average grades obtained by degree courses.

\begin{tabular}{cccc}
\hline $\begin{array}{c}\text { Degree } \\
\text { Statistical }\end{array}$ & CAU * & CAUP ** & Journalism \\
\hline $\bar{X}(\mathrm{SD})$ & $8.53(0.39)$ & $7.60(0.79)$ & $8.53(0.38)$ \\
\hline Minimum & 7.78 & 5.61 & 7.77 \\
\hline Maximum & 9.23 & 8.84 & 9.49 \\
\hline${ }^{*}$ Degree in Audiovisual Communication; ${ }^{* *}$ Joint Honours Degree in Audiovisual Communication and Journalism.
\end{tabular}

(b) Satisfaction and achievements attained

With regard to satisfaction with the project reported by the participating students, good results were also obtained. The total mean of the scale reached a value of 39 points (SD $=6.99$ ) out of 50 , with mode values of 40 and 43 (bimodal distribution). After applying a variance analysis, the results did not show statistically significant differences between the means of the satisfaction and achievements scale $\left(\bar{X}_{\mathrm{CAU}}=38.48, \mathrm{SD}=6.69 ; \bar{X}_{\mathrm{CAUP}}=39.77\right.$, $\left.\mathrm{SD}=6.48 ; \bar{X}_{\text {PERIODISMO }}=38.96, \mathrm{SD}=7.45\right)$, depending on the degree course $(\mathrm{F}=0.373$; $p=0.689$ ).

With regard to the descriptions of each item (Table 3), the highest mean scores were obtained for those referring to whether students, once the project was completed, would recommend future students to take part in the same project, as well as for the item assessing 
overall satisfaction with the project. Again, statistically significant differences were not found in any of the items depending on the degree course taken by the students (Table 3).

Table 3. Descriptions of the items of the satisfaction scale and ANOVA 1F.

\begin{tabular}{|c|c|c|c|c|c|c|}
\hline Interest in psychology & $\bar{X}(\mathrm{SD})$ & Mode & Minimum & Maximum & $F$ & $p$ \\
\hline TOTAL & $7.13(1.92)$ & 7 & 1 & 10 & & \\
\hline $\mathrm{CAU} *$ & $7(1.82)$ & 7 & 1 & 10 & \multirow{3}{*}{0.182} & \multirow{3}{*}{0.834} \\
\hline CAUP ** & $7.23(1.99)$ & 8 & 1 & 10 & & \\
\hline JOURNALISM & $7.17(1.96)$ & 7 & 1 & 10 & & \\
\hline $\begin{array}{c}\text { Applying theoretical } \\
\text { knowledge in a } \\
\text { practical way }\end{array}$ & $\bar{X}(\mathrm{SD})$ & Mode & Minimum & Maximum & \multirow[t]{2}{*}{$\mathrm{F}$} & \multirow[t]{2}{*}{$p$} \\
\hline TOTAL & $7.62(1.67)$ & 7 & 1 & 10 & & \\
\hline CAU * & $7.42(1.69)$ & 7 & 1 & 10 & \multirow{3}{*}{0.685} & \multirow{3}{*}{0.505} \\
\hline CAUP ** & $7.56(1.68)$ & 7 & 1 & 10 & & \\
\hline JOURNALISM & $7.77(1.67)$ & 9 & 1 & 10 & & \\
\hline Satisfaction with the subject & $\bar{X}(\mathrm{SD})$ & Mode & Minimum & Maximum & \multirow{2}{*}{$\mathrm{F}$} & \multirow{2}{*}{$p$} \\
\hline TOTAL & $7.43(1.84)$ & 8 & 1 & 10 & & \\
\hline CAU * & $7.44(1.80)$ & 8 & 1 & 10 & \multirow{3}{*}{0.031} & \multirow{3}{*}{0.969} \\
\hline CAUP ** & 7.49 (1.65) & 7 & 1 & 10 & & \\
\hline JOURNALISM & 7.40 (1.97) & 8 & 1 & 10 & & \\
\hline $\begin{array}{l}\text { You would recommend } \\
\text { future students to take part }\end{array}$ & $\bar{X}(\mathrm{SD})$ & Mode & Minimum & Maximum & \multirow{2}{*}{$\mathrm{F}$} & \multirow{2}{*}{$p$} \\
\hline TOTAL & $8.60(1.42)$ & 10 & 1 & 10 & & \\
\hline CAU * & $8.56(1.37)$ & 10 & 1 & 10 & \multirow{3}{*}{1.033} & \multirow{3}{*}{0.358} \\
\hline CAUP ** & $8.87(1.22)$ & 10 & 1 & 10 & & \\
\hline JOURNALISM & $8.47(1.54)$ & 10 & 1 & 10 & & \\
\hline $\begin{array}{c}\text { Overall satisfaction with } \\
\text { the project }\end{array}$ & $\bar{X}(\mathrm{SD})$ & Mode & Minimum & Maximum & \multirow{2}{*}{$\mathrm{F}$} & \multirow{2}{*}{$p$} \\
\hline TOTAL & $8.23(1.35)$ & 8 & 1 & 10 & & \\
\hline CAU * & $8.04(1.18)$ & 9 & 1 & 10 & \multirow{3}{*}{2.250} & \multirow{3}{*}{0.109} \\
\hline CAUP $^{* *}$ & $8.62(1.18)$ & 9 & 1 & 10 & & \\
\hline JOURNALISM & $8.15(1.5)$ & 8 & 1 & 10 & & \\
\hline
\end{tabular}

\section{(c) Attitudes}

Meanwhile, the overall mean of attitudes reached a value of 29.16 (6.91), out of a maximum score of 40 and a mode value of 35 , whereby it may be affirmed that students, after taking part in the project, carried out a good assessment of The Fundamentals of Psychology course. After applying a variance analysis, the results did not show significant differences in mean attitudes $\left(\bar{X}_{\mathrm{CAU}}=28.9, \mathrm{SD}=7.11 ; \bar{X}_{\mathrm{CAUP}}=29.74, \mathrm{SD}=7.47\right.$; $\left.\bar{X}_{\text {PERIODISMO }}=29.03, \mathrm{SD}=6.55\right)$, depending on the degree course $(\mathrm{F}=0.187 ; p=0.829)$.

After also calculating the descriptions of each item (Table 4), the highest scores were obtained for those items referring to the extent that they were glad that they are able to take a psychology course in their degree and their intention to take one in the event that they had been able to choose (as it is a core subject in the curriculum). As in the case of the measures of satisfaction with the project, no significant differences were found between the means of any of the attitude items, depending on the degree course (Table 4). 
Table 4. Descriptions of items of the attitudes scale and ANOVA 1F.

\begin{tabular}{|c|c|c|c|c|c|c|}
\hline $\begin{array}{c}\text { I feel motivated to take } \\
\text { the course }\end{array}$ & $\bar{X}(\mathrm{SD})$ & Mode & Minimum & Maximum & $\mathrm{F}$ & $p$ \\
\hline TOTAL & 7.32 (1.65) & 7 & 3 & 10 & & \\
\hline CAU * & $7.22(1.77)$ & 7 & 3 & 10 & \multirow{3}{*}{0.576} & \multirow{3}{*}{0.563} \\
\hline $\mathrm{CAUP}^{* *}$ & $7.56(1.65)$ & 8 & 3 & 10 & & \\
\hline JOURNALISM & $7.26(1.57)$ & 7 & 3 & 10 & & \\
\hline $\begin{array}{c}\text { If it were optional, I would } \\
\text { choose it to complete } \\
\text { my training }\end{array}$ & $\bar{X}(\mathrm{SD})$ & Mode & Minimum & Maximum & \multirow[t]{2}{*}{$\mathrm{F}$} & \multirow[t]{2}{*}{$p$} \\
\hline TOTAL & $6.74(2.18)$ & 8 & 1 & 10 & & \\
\hline CAU* & $6.68(2.11)$ & 6 & 2 & 10 & \multirow{3}{*}{0.137} & \multirow{3}{*}{0.872} \\
\hline CAUP ** & $6.90(2.50)$ & 8 & 1 & 10 & & \\
\hline JOURNALISM & $6.69(2.09)$ & 8 & 2 & 10 & & \\
\hline $\begin{array}{l}\text { I am glad that this degree } \\
\text { has a course in psychology }\end{array}$ & $\bar{X}(\mathrm{SD})$ & Mode & Minimum & Maximum & \multirow{2}{*}{$\mathrm{F}$} & \multirow{2}{*}{$p$} \\
\hline TOTAL & $7.46(1.79)$ & 8 & 2 & 10 & & \\
\hline $\mathrm{CAU}^{*}$ & $7.46(1.76)$ & 8 & 2 & 10 & \multirow{3}{*}{0.024} & \multirow{3}{*}{0.976} \\
\hline CAUP ** & $7.41(2.06)$ & 10 & 3 & 10 & & \\
\hline JOURNALISM & 7.49 (1.67) & 7 & 5 & 10 & & \\
\hline $\begin{array}{l}\text { If I had been able to choose, I } \\
\text { would have taken a course } \\
\text { in psychology in this degree }\end{array}$ & $\bar{X}(\mathrm{SD})$ & Mode & Minimum & Maximum & \multirow[t]{2}{*}{$\mathrm{F}$} & \multirow[t]{2}{*}{$p$} \\
\hline TOTAL & $7.64(2.19)$ & 10 & 1 & 10 & & \\
\hline CAU * & $7.54(2.33)$ & 10 & 1 & 10 & \multirow{3}{*}{0.288} & \multirow{3}{*}{0.750} \\
\hline CAUP ** & 7.87 (1.96) & 10 & 3 & 10 & & \\
\hline JOURNALISM & $7.59(2.23)$ & 10 & 3 & 10 & & \\
\hline
\end{tabular}

*Audiovisual Communication Degree; ${ }^{* *}$ Joint Honours in Audiovisual Communication and Journalism.

\subsection{Bivariate Analysis and Modelling}

Pearson's correlation coefficient was calculated to determine the extent of the relationship between the total measure of attitudes towards the subject and satisfaction with the project. A result of $\mathrm{r}_{\mathrm{yx}}=0.334(p=0.000)$ was obtained, which indicates that the $11.2 \%$ of the total variance of attitudes is explained by the satisfaction and achievements attained after completing MICROFEST. This result shows that, in addition to satisfaction with the project, there are other predictors of students' assessment of the course.

In order to investigate what the project has achieved and which aspects have been assessed using the satisfaction variable, and to explain the positive attitudes towards the course, Pearson's correlation coefficients were also obtained between all the indicators of both variables (Table 5). Specifically, and taking into account the attitude that covaries most with the rest of the indicators, we can affirm that the greater the satisfaction and achievements attained with the MICROFEST project, the greater the motivation to take the course. 
Table 5. Correlations between satisfaction and attitude indicators.

\begin{tabular}{|c|c|c|c|c|c|}
\hline $\begin{array}{ll}\text { Attitudes Course } \\
\end{array}$ & $\begin{array}{l}\text { Increased Interest } \\
\text { in Psychology }\end{array}$ & $\begin{array}{l}\text { Application of } \\
\text { Theoretical } \\
\text { Knowledge }\end{array}$ & $\begin{array}{c}\text { Increased } \\
\text { Satisfaction with } \\
\text { Course }\end{array}$ & $\begin{array}{l}\text { Would You Recommend } \\
\text { Future Students to Take Part }\end{array}$ & $\begin{array}{l}\text { Overall } \\
\text { Satisfaction with } \\
\text { Project }\end{array}$ \\
\hline Motivated to take the course & $0.447^{* *}$ & $0.313 * *$ & $0.402 * *$ & $0.269 * *$ & $0.369 * *$ \\
\hline If it were optional, I would choose it & $0.226^{* *}$ & $0.208^{* *}$ & $0.226 * *$ & $0.209 * *$ & $0.266^{* *}$ \\
\hline I am glad this course is in the degree & $0.267 * *$ & $0.251 * *$ & $0.236^{* *}$ & $0.207 * *$ & $0.302 * *$ \\
\hline If I could choose, I would take it & $0.199 * *$ & $0.172 *$ & $0.184 *$ & $0.196^{*}$ & $0.240 * *$ \\
\hline
\end{tabular}

Bearing in mind the importance of this motivational component for the teachinglearning process, a multiple linear regression analysis was carried out to analyse the combined influence of these satisfaction indicators and thus determine, with a view to the development of future initiatives, which of them could be good predictors of this attitude component. After applying a simultaneous construction method, a model with a size effect of $\hat{R}^{2}=0.210$ was obtained. Of the five satisfaction variables introduced in the model, increased interest in psychology after completing the project $(\beta=0.329 ; \mathrm{t}=2.816, p=0.005$; $\left.\mathrm{S}_{\mathrm{rINTEREST}}=0.194\right)$ and overall satisfaction with the same $(\beta=0.237 ; \mathrm{t}=2.113, p=0.036$; $\mathrm{S}_{\mathrm{rSATISFACTION}}=0.146$ ) were found to be moderate but significant predictors of motivation to take the course.

\section{Discussion and Conclusions}

This paper analyses the impact that the MICROFEST university educational innovation project has had on academic performance, attitudes towards the Fundamentals of Psychology course and satisfaction and achievement with the innovation project among first-year social sciences degree students.

As observed in previous educational innovation studies (Huber et al. 2017; Malá and Čerešník 2015; Turcsányi-Szabó 2012), using theoretical approaches such as Bloom's revised approach (Krathwohl 2002) in the planning of innovation activities allows the teaching-learning process of students to be organised better. It was also shown that the definition of clear objectives has a positive impact on people's motivation, as argued by the motivational theory of self-determination (Ryan and Deci 2000), and this, in turn, influences academic performance (Maquión-Sánchez and Hernández-Pina 2011). The use of this taxonomy in the organisation and description of the MICROFEST educational innovation activity had a positive impact on students that took part in the initiative. This could be seen in academic performance, which has been excellent in all degree courses involved in the project. For their part, the attitudes displayed by students towards the course are positive and, after taking part in the project, overall satisfaction with the same and with the course was high, bearing in mind that the initiative also raised their interest in psychology.

Regarding differences found in degrees that took part in MICROFEST, the hypothesis tests carried out in the study only showed statistically significant differences in performance between the groups, being higher in courses in which the activity was compulsory (Audiovisual Communication and Journalism). Meanwhile, satisfaction and attitudes towards the course, although not statistically significant, did show better results overall in the group for whom the activity was voluntary (Joint Honours in Audiovisual Communication and Journalism). As a whole, these data could indicate that university students need to carry out activities such as this on a compulsory basis to improve their performance and achieve excellence in this subject. However, in order to raise satisfaction and positive attitudes towards the same, it would be advisable to also provide them with alternatives that would allow them to choose the type of compulsory activity to be carried out.

By increasing the degree of the students' control over the activity, the locus of causality is transferred within the individual, which increases students' intrinsic motivation and improves their emotional experience by making them feel that their achievements depend on their performance (Ryan and Deci 2000). Likewise, and as traditionally pro- 
posed in classical literature (Bandura 1997; Fernández-Castro and Edo-Izquierdo 1994; Rotter 1966), perceived control is related to positive emotional and cognitive states, which could explain the higher scores in satisfaction and attitudes towards the subject and the poorer performance in the degree where the activity was voluntary.

Furthermore, another aspect that may explain the difference found in performance is the value of the reinforcement obtained after completing the project. While the value of the activity in the Joint Honours programme was $10 \%$ of the final subject grade, it was 30\% in Audiovisual Communication and Journalism, with students of the latter two degrees achieving a better academic performance in the activity. This may indicate an increase in their extrinsic motivation to obtain the reinforcement that influenced them to try harder to carry out the activity. In the same way, this finding is consistent with the principles of instrumental learning applied in an academic context (Cepeda et al. 2018), where positive reinforcement has been found to be the best procedure for raising motivated behaviour in the classroom and improving academic performance (Maquión-Sánchez and Hernández-Pina 2011).

Finally, the results of the correlations between the assessments of the project and the course indicate that, in addition to satisfaction and achievements attained after taking part in this initiative, there are other factors that would explain to a greater extent the attitudes shown by students towards the subject. This makes sense if we take into account that, in addition to factors of a different nature, such as each student's preferences for and interest in certain subjects, the course includes other parts (theoretical and practical) taught, in some cases, by different teachers and involves the application of other teaching strategies other than those applied in this project, to cover the rest of their objectives within the syllabus. We understand that these factors, which have not been analysed as they are not the object of this paper, may also be influencing attitudes.

It should be noted, however, that when the relationships between the indicators of each variable are analysed, and the joint influence of those used to assess satisfaction with the project, the increase in interest in psychology achieved by this initiative and overall satisfaction after taking part are found to be good predictors of students' motivation to take the course, a factor deemed to be highly relevant for the success of the teaching-learning process (Maquión-Sánchez and Hernández-Pina 2011; Prieto Andreu 2020).

With regard to the strengths and limitations of the study, we have not found evidence that shows that the type of degree and, therefore, the teaching staff, when it comes to implementing the project, influenced most of the variables analysed, so we can affirm that the study has been well designed and well implemented. We have also had the opportunity to test the experience under various conditions related to the opportunity to choose and the reinforcement obtained by students after taking part in the same. However, the differences in performance found depending on it being voluntary and its weight in the continuous assessment suggest that it would have been preferable to implement the project on a compulsory basis in all degrees, applying a fairer weighting in the total grade for the course, bearing in mind the effort involved in completing it.

We believe that the MICROFEST project should be generalised and implemented in successive years for two reasons. First, the sample of participants represents $83 \%$ of the student population of the degrees included in the project, a sample size that we think is more than representative of the total in the current academic year. Second, the performance indicators obtained in past years of these degrees were worse than the current year since there was a significantly higher rate of failed students and lower class attendance than during the months of application of the present project, which justified the development of this educational innovation initiative.

In this sense, it is necessary to bear in mind that the only difference in the teaching given during the past courses and the current one is that the MICROFEST project offered students the possibility of learning psychology through a teaching methodology different from the traditional lectures as explained above. For this reason, we consider that the results obtained in this preliminary descriptive study are more than satisfactory and would justify 
its continued application in the future in these degrees in the subject of Fundamentals of Psychology. Notwithstanding the above, to better specify its benefits, it would be advisable to continue researching following an experimental or quasi-experimental methodology to analyse the effectiveness of MICROFEST to improve the teaching-learning process.

In conclusion, through the MICROFEST initiative implemented in the Fundamentals of Psychology course in the Audiovisual Communication, Journalism and joint Honours degree programmes at Miguel Hernández University during the 2020/2021 academic year, presented in this paper, good results were obtained in performance, and high satisfaction was present among participating students, whose indicators, furthermore, were found to be good predictors of their motivation for the subject. It is therefore recommended that integrated innovative teaching strategies be designed that allow students to apply digital and communication skills related to their degrees, through the implementation of activities capable of arousing interest in other disciplines such as psychology.

Author Contributions: Conceptualization, R.B.O., B.B.-L. and R.L.-M.; methodology, R.B.O. and R.L.-M.; formal analysis, R.B.O.; resources, R.B.O., B.B.-L. and R.L.-M.; data curation, R.B.O.; writingoriginal draft preparation R.L.-M.; writing-review and editing, R.B.O. and R.L.-M.; visualization, R.L.-M.; supervision, Rebeca Bautista-Ortuño and R.L.-M.; project administration, R.B.O.; funding acquisition, R.B.O., B.B.-L. and R.L.-M. All authors have read and agreed to the published version of the manuscript.

Funding: This research was funded by PIEU-UMH grant number 2020/22 And the APC was funded by Miguel Hernandez University.

Institutional Review Board Statement: This project was approved for implementation by the Miguel Hernandez University Vice-Rector's Office for Studies, and the data collected is part of the continuous assessment process applied in the course of Fundamentals of Psychology during the 2020-2021 academic year.

Informed Consent Statement: Informed consent was obtained from all subjects involved in the study.

Data Availability Statement: The data presented in this study are available on request from the corresponding author.

Acknowledgments: This study has been possible thanks to the granting of the PIEU-UMH 2020/22 project called MICROFEST, and its implementation as part of the continuous assessment of the Fundamentals of Psychology course, taught in the Audiovisual Communication, Journalism and Joint Honours Audiovisual Communication and Journalism degree programmes at the Miguel Hernandez University, during the 2020/2021 academic year.

Conflicts of Interest: The authors declare no conflict of interest. 


\section{Appendix A}

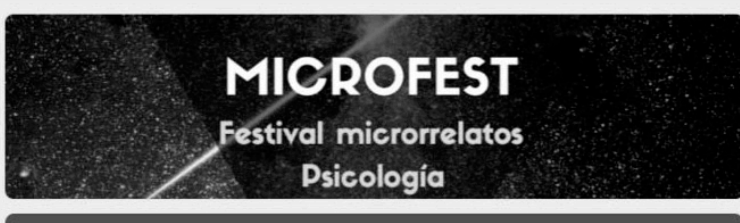

PLANTILLA EVALUACIÓN

MICRORRELATOS AUDIOVISUALES. FUNDAMENTOS DE LA PSICOLOGÍA.

GRADO:

CURSO 2021/2022

Siguiente

Nunca envies contraseñas a través de Formularios de Google.

\section{Información estudiante que evalúa}

Apellidos y nombre

Tu respuesta

Dirección de email

Tu respuesta

Número de grupo de trabajo al que perteneces *

Elige

Atrás

Siguiente

\section{Microrrelato (no): (TituLo)}

Autores/as:

Valora de 0 a 10 en qué medida te parece que el microrrelato audiovisual REFLEJA EL CONCEPTO O TEMA PSICOLOGICO sobre el que trata.

$$
\text { Elige }
$$

Puntủa de 0 a 10 en qué medida valoras la ORIGINALIDAD/CREATIVIDAD del microrrelato audiovisual. *

Elige

Asigna al microrrelato una nota de 0 a 10 segủn CUÁNTO TE HA GUSTADO EN GENERAL.

Elige

Por último, en cuanto a la PARTE DE PRESENTACION DE LOS/AS AUTORES/AS, valora de $\mathrm{O}$ a 10 en qué medida crees que las habilidades de comunicación y exposición oral que han mostrado se ajustan a los criterios conductuales de la comunicación verbal, no verbal y paraverbal. *

Elige

Atrás
Micro-story $\left(n^{\circ}\right)$ : "(TITLE)"

Author(s)

Assess from 0 to 10 to what extent you believe that the audiovisual micro-story REFLECTS THE PSYCHOLOGICAL CONCEPT OR THEME it addresses. *

Choose

Score from 0 to 10 your assessment of the ORIGINALITY/CREATIVITY of the audiovisual micro-story. *

Choose

Give the micro-story a score from 0 to 10 according to HOW MUCH YOU LIKED IT OVERALL. *

Choose

Finally, with regard to the PRESENTATION PART BY THE ALTHOR(S), assess from 0 to 10 the extent to which you believe that the communication and oral expression skills displayed conform to the behavioural criteria of verbal, non-verbal and paraverbal communication. *

Choose

Back Send

Note: * questions with compulsory answers. + The number was previously assigned by lecturers and students had to write down that number. 


\section{Appendix B}

\begin{tabular}{|c|}
\hline $\begin{array}{l}\text { Cuestionario Fundamentos de la } \\
\text { Psicologia } \\
\text { obiligatorio }\end{array}$ \\
\hline $\begin{array}{l}\text { Te identificas como.... } \\
\bigcirc \text { Hombre } \\
\bigcirc \text { Mujer } \\
\bigcirc \text { otro } \\
\bigcirc \text { Prefiero no decirlo }\end{array}$ \\
\hline $\begin{array}{l}\text { Edad (introduce solo el valor numérico) } \\
\text { Tu respuesta }\end{array}$ \\
\hline $\begin{array}{l}\text { Edad (introduce solo el valor numérico) * } \\
\text { Tu respuesta }\end{array}$ \\
\hline $\begin{array}{l}\text { Soy estudiante del grado en.... } \\
\text { Comunicación audiovisual } \\
\text { Doble grado CAUP } \\
\text { Periodismo }\end{array}$ \\
\hline Siguiente \\
\hline
\end{tabular}

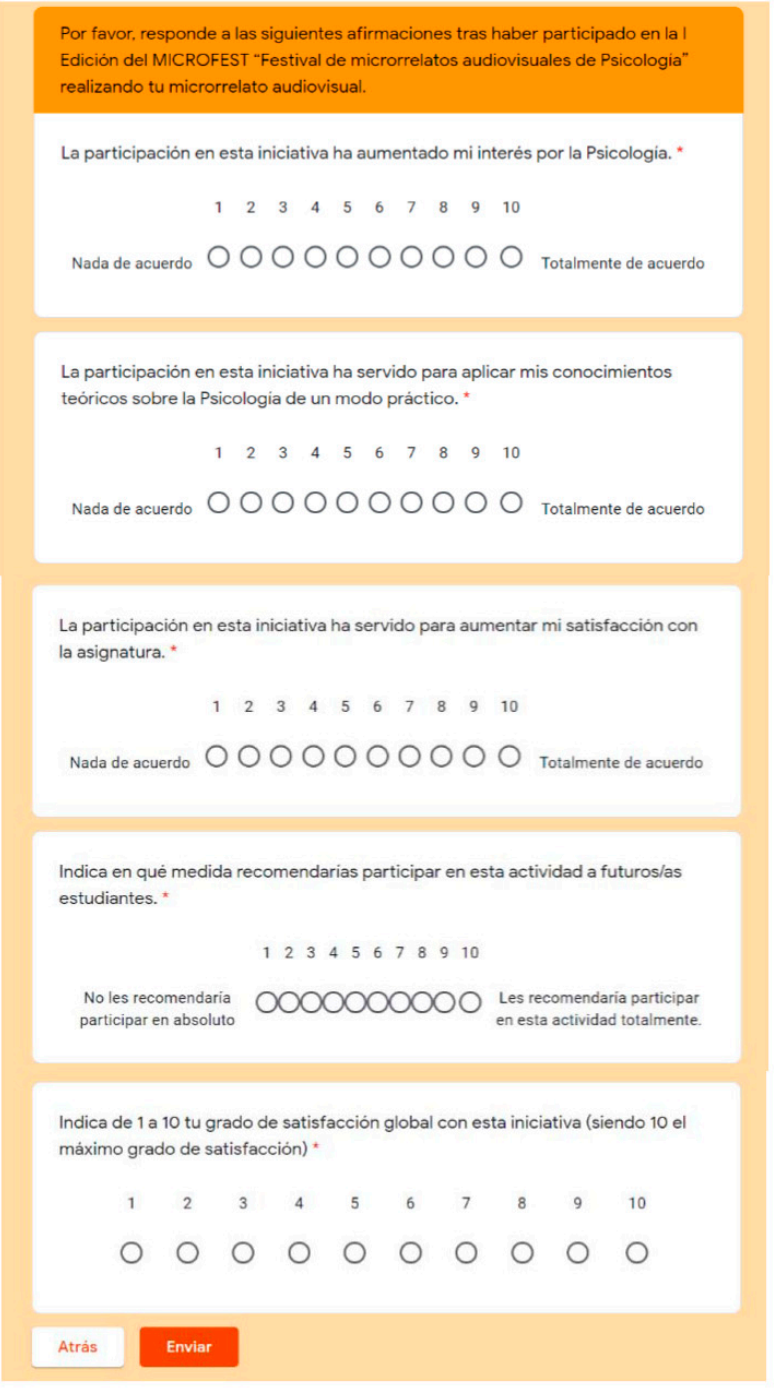

\footnotetext{
Fundamentals of Psychology Questionnair

*Compulsory

You identify as a... +

Man

Woman

Other

I prefer not to say

Age (only enter the numerical value) *

Your response

I am studying for a degree in... *

Audiovisual Communication

Joint Honours CAUP

Journalism

Next

Never send passwords via Google Forms
}

Please respond to the following statements after taking part in the first edition of MICROFEST "Festival of Psychology micro-stories" making your audiovisual microstory

Taking part in this initiative has raised my interest in Psychology. *

Strongly disagree 12345678910 Totally agree

Taking part in this initiative has served to apply my theoretical knowledge about Psychology in a practical way. *

Strongly disagree 12345678910 Totally agree

Taking part in this initiative has served to raise my satisfaction with the subject. *

Strongly disagree 12345678910 Totally agree

Indicate to what extent you would recommend future students to take part in this activity. "

I absolutely would not recommend 123456789101 would absolutely

they take part recommend taking part in this activity

Indicate from 1 to 10 your degree of satisfaction with this initiative ( 10 being the highest degree of satisfaction). *

12345678910

Back Send

Note: * questions with compulsory answers. + The number was previously assigned by lecturers and students had to write down that number. 


\section{Appendix C}

Por favor, responde a las siguientes afirmaciones según tu grado de acuerdo con ellas. Recuerda que no hay respuestas ni correctas ni incorrectas y que es muy importante que contestes con sinceridad.

Creo que los conocimientos que puede aportar la asignatura de Fundamentos de la Psicologia NO SON ÚTILES para el grado que estoy estudiando. (item eliminado tras análisis de fiabilidad)

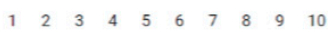

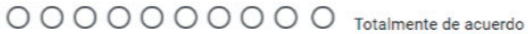

Nada de acuerdo

Me siento motivado/a por cursar esta asignatura de Psicologia. *

$\begin{array}{llllllllll}1 & 2 & 3 & 4 & 5 & 6 & 7 & 8 & 9 & 10\end{array}$

Nada de acuerdo

$\bigcirc \bigcirc \bigcirc \bigcirc \bigcirc \bigcirc \bigcirc \bigcirc \bigcirc \bigcirc$ Totalmente de acuerdo

Si la asignatura de Fundamentos de la Psicologia fuera optativa, la elegiria seguro para complementar mi formación. *

$\begin{array}{lllllllll}2 & 3 & 4 & 5 & 6 & 7 & 8 & 9 & 10\end{array}$

Nada de acuerdo $\mathrm{O} \bigcirc \mathrm{O} \bigcirc \bigcirc \bigcirc \bigcirc \bigcirc$ Totalmente de acuerdo

Creo que la Psicologia NO ES una disciplina interesante. (item eliminado tras análisis de fiabilidad) *

$\begin{array}{llllllllll}1 & 2 & 3 & 4 & 5 & 6 & 7 & 8 & 9 & 10\end{array}$

Nada de acuerdo $\mathrm{O} \bigcirc \mathrm{O} \bigcirc \mathrm{O} \bigcirc \mathrm{O}$ Totalmente de acuerdo

Me alegra poder tener una asignatura de Psicologia en este grado.

$\begin{array}{llllllllll}1 & 2 & 3 & 4 & 5 & 6 & 7 & 8 & 9 & 10\end{array}$

0000000000 Totalmente de acuerdo

Nada de acuerdo

Si hubiera podido elegir, NO cursaria una asignatura de Psicologia en este grado.

$\begin{array}{llllllllll}1 & 2 & 3 & 4 & 5 & 6 & 7 & 8 & 9 & 10\end{array}$

Nada de acuerdo $\bigcirc \bigcirc \bigcirc \bigcirc \bigcirc \bigcirc \bigcirc \bigcirc \bigcirc \bigcirc$ Totalmente de acuerdo
Please respond to the following statements according to the

extent to which you agree with them. Remember that there are no correct or incorrect answers, and the important thing is that you respond sincerely.

I believe that the knowledge provided by the Fundamentals of Psychology course IS NOT USEFUL in the degree that I am studying for (item deleted after reliability analysis) .

Strongly disagree 12345678910 Totally agree

I feel motivated to take this Psychology course *

Strongly disagree 12345678910 Totally agree

If the Fundamentals of Psychology course were optional, would definitely choose it to complete my training.

Strongly disagree 12345678910 Totally agree

I believe that Psychology IS NOT an interesting discipline (item deleted after reliability analysis). *

Strongly disagree 12345678910 Totally agree

1 am glad that there is a Psychology course in this degree. *

Strongly disagree 12345678910 Totally agree

If I had had the choice, I would NOT have taken this Psychology course in this degree programme. *

Strongly disagree 12345678910 Totally agree

Note: * questions with compulsory answers. 


\section{Appendix D}

\section{MICRO-STORY SCRIPT FORM}

(eliminated for the double-blind peer review) 2020/ 22 (2020-21 Academic Year)

\begin{tabular}{|c|c|}
\hline \multicolumn{2}{|c|}{ TÍTULO DEL MICRORRELATO } \\
\hline \multicolumn{2}{|c|}{ AUTORÍA (indica los datos de identificación de la/s persona/s que realizan el trabajo) } \\
\hline $\begin{array}{l}\text { DNI } \\
\text { Nombre y Apellidos }\end{array}$ & \\
\hline \multicolumn{2}{|c|}{ TEMA DEL MICRORRELATO } \\
\hline $\begin{array}{l}\text { Define con una } \\
\text { palabra o frase cuál } \\
\text { es el tema principal } \\
\text { del microrrelato. }\end{array}$ & \\
\hline \multicolumn{2}{|c|}{ VINCULACIÓN DEL TEMA CON LOS CONTENIDOS TEÓRICOS DE LA ASIGNATURA } \\
\hline $\begin{array}{l}\text { ¿Con qué tema de la } \\
\text { asignatura se } \\
\text { relaciona? }\end{array}$ & \\
\hline $\begin{array}{l}\text { Justificación } \\
\text { (explica y documenta, } \\
\text { esto es, referencia las } \\
\text { fuentes de información } \\
\text { que muestren cómo se } \\
\text { relaciona el tema } \\
\text { elegido del microrrelato } \\
\text { con el contenido de la } \\
\text { asignatura indicado). }\end{array}$ & \\
\hline \multicolumn{2}{|c|}{ GUIÓN DEL MICRORRELATO } \\
\hline $\begin{array}{l}\text { Plan de Ejecución } \\
\text { Describe el borrador } \\
\text { del guion (ideas } \\
\text { previas) que tenéis en } \\
\text { mente utilizar para } \\
\text { plasmar el tema elegido } \\
\text { en el microrrelato. }\end{array}$ & \\
\hline
\end{tabular}

\footnotetext{
TITLE OF MICRO-STORY

AUTHORSHIP (provide D details for the person(s) that are doing the work)

DNI (National ID Document)

Name and Sumame(s)

THEME OF THE MICRO-STORY

In one word or phrase, define the main theme of the micro-story)

LINK BETWEEN THEME AND THEORETICAL CONTENT OF THE COURSE

Which course theme is is related to?

Justification

(explain and document, in other words, reference the sources of information that show how the theme chosen for the micro-story relates to the content of the course indicated).

MICRO-STORY SCRIPT

Plan of execution

Describe the outline of the script (previous ideas) that you have in mind to use to capture the theme chosen in the micro-story.
} 


\section{References}

Ávila, Carolina, and Simon Betancur. 2017. La Gamificación En La Educación Superior: Una Revisión Sistemática. Revista Ingenierías Universidad de Medellín 16: 97-124. [CrossRef]

Bandura, Albert. 1997. Self-Efficacy: The Exercise of Control/Albert Bandura. New York: W.H. Freeman.

Bujanda-Bujanda, María Eugenia, Valeria Ruiz-González, Andrea Molina-Ovares, and Sofia Quesada-Montano. 2014. Competencias Del S. XXI Guía Práctica Para Promover Su Aprendizaje y Su Evaluación. San José: Fundación Omar Dengo. Available online: https://issuu.com/libiamijares/docs/competencias_del_siglo_xxi (accessed on 26 July 2021).

Cepeda, Helen Iveth Figueroa, Karlita Elizabeth Muñoz Correa, Edwin Vinício Lozano, and Diego Fernando Zavala Urquizo. 2018. Análisis Crítico del Conductismo y Constructivismo, como Teorías de Aprendizaje en Educación. Open Journal Systems en Revista: Revista de Entrenamiento 4: 1-12.

Doherty, Shawn, Evan Palmer, and Laura Strater. 2017. Gamification: Current Research and Applications. Proceedings of the Human Factors and Ergonomics Society Annual Meeting 61: 2096-99. [CrossRef]

Dreimane, Santa. 2019. Gamification for Education: Review of Current Publications. In Didactics of Smart Pedagogy: Smart Pedagogy for Technology Enhanced Learning. Edited by Linda Daniela. Cham: Springer International Publishing, pp. 453-64. [CrossRef]

European Commision. 2021. Digital Competence Framework for Educators (DigCompEdu). [Folleto]. Available online: https: / / ec.europa.eu/jrc/sites/jrcsh/files/digcompedu_folleto_10-11-20_es.pdf (accessed on 26 July 2021).

Fernández-Castro, Jordi, and Silvia Edo-Izquierdo. 1994. ¿Cómo influye el control percibido en el impacto que tienen las emociones sobre la salud? Anales de Psicología 10: 127-33.

Garrote Rojas, Daniel, Cristina Garrote Rojas, and Sara Jiménez Fernández. 2016. Factores influyentes en motivación y estrategias de aprendizaje en los alumnos de grado. REICE. Revista Iberoamericana Sobre Calidad, Eficacia y Cambio en Educación 14. [CrossRef]

Huber, Marsha, Dave Law, and Ashraf Khallaf. 2017. Active Learning Innovations in Introductory Financial Accounting. In Advances in Accounting Education: Teaching and Curriculum Innovations. Advances in Accounting Education. Bingley: Emerald Publishing Limited, vol. 21, pp. 125-67. [CrossRef]

Indriasari, Theresia Devi, Andrew Luxton-Reilly, and Paul Denny. 2020. Gamification of Student Peer Review in Education: A Systematic Literature Review. Education and Information Technologies 25: 5205-34. [CrossRef]

Krathwohl, David R. 2002. A Revision of Bloom's Taxonomy: An Overview. Theory into Practice 41: 212-18. [CrossRef]

Lee, Joey J., and Jessica Hammer. 2011. Gamification in Education: What, How, Why Bother? Academic Exchange Quarterly 15: 146.

Malá, Dana, and Michal Čerešník. 2015. The Evaluation of the Course Description Quality by Students of the Psychology Teaching Training Programme. Procedia Social and Behavioral Science 174: 3523-30. [CrossRef]

Maquión-Sánchez, Javier J., and Fuensanta Hernández-Pina. 2011. Influencia de la motivación en el rendimiento académico de los estudiantes de formación profesional. Revista Electrónica Interuniversitaria de Formación del Profesorado 14: 81-100.

Ministerio de Educación. 2011. Estudio Sobre la Innovación Educativa en España. Madrid: Instituto de Formación del Profesorado, Investigación e Innovación Educativa, p. 17.

Piaget, Jean. 1976. Piaget's Theory. In Piaget and His School: A Reader in Developmental Psychology. Springer Study Edition. Edited by Bärbel Inhelder, Harold H. Chipman and Charles Zwingmann. Berlin/Heidelberg: Springer, pp. 11-23. [CrossRef]

Prieto Andreu, Joel Manuel. 2020. Una revisión sistemática sobre gamificación, motivación y aprendizaje en universitarios. Teoría de la Educación. Revista Interuniversitaria 32: 73-99. [CrossRef]

Redecker, Christine. 2017. European Framework for the Digital Competence of Educators: DigCompEdu; EUR 28775 EN, JRC Science for Policy Report. Luxenbourg: European Union. Available online: https:/ / ec.europa.eu/jrc/en/publication/eur-scientific-andtechnical-research-reports / european-framework-digital-competence-educators-digcompedu (accessed on 26 July 2021).

Rotter, Julian B. 1966. Generalized Expectancies for Internal versus External Control of Reinforcement. Psychological Monographs 80: 1-28. [CrossRef] [PubMed]

Ryan, Richard M., and Edward L Deci. 2000. La Teoría de la Autodeterminación y la Facilitación de la Motivación Intrínseca, el Desarrollo Social, y el Bienestar. American Psychologist 55: 68-78. [CrossRef]

Søndergaard, Harald, and Raoul A. Mulder. 2012. Collaborative Learning through Formative Peer Review: Pedagogy, Programs and Potential. Computer Science Education 22: 343-67. [CrossRef]

Topping, Keith. 1998. Peer Assessment between Students in Colleges and Universities. Review of Educational Research 68: $249-76$. [CrossRef]

Turcsányi-Szabó, Márta. 2012. Aiming at Sustainable Innovation in Teacher Education-From Theory to Practice. Informatics in Education-An International Journal 11: 115-30. [CrossRef] 